\title{
CROSS-BORDER LABOR MIGRATION IN EUROPE: A VIEW FROM THE EMERGING CIVIL SOCIETY IN UKRAINE
}

\author{
MAKSYMILIAN DUBNYAK \\ OLEnA Koshmanova \\ okoshmanova@luc.edu
}

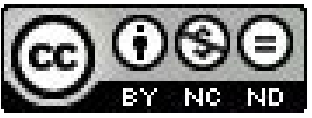

\begin{abstract}
Using a case study approach, the paper analyzes available research on the topic of identifying and the effects that cross border wage labor migration makes on the Ukrainian family and on the development of the emerging civil society in Ukraine. The goal of the article is two-fold: to enrich the pool of knowledge on Ukrainian female migrants to Europe, and to engage with recent literature on the role that transnational migration plays in relation to the family and the sending country as part of transnational civil society
\end{abstract}

Key words: labor migration, sending country, civil society, globalization.

\section{INTRODUCTION}

After the breakup of the Soviet Union, Ukraine, among the other fourteen newly formed independent countries, faced many challenges in their transitional period to the market economy and civil society. Severe unemployment, rising crime rates, inflation and a general state of chaos characterized the first half of the 1990s in Ukraine after its long awaited Independence (1991). Mass emigration started taking place to many Western countries, including USA, Canada, Australia and Western Europe. This occurrence became less severe as the economic situation in the country began to stabilize in recent years. Nevertheless, a new phenomenon arose because of social anomie and low wages, which promoted wage labor migration.

This paper will focus on the problems of international labor migration and the impacts which it makes on the deterioration of families left behind. Within the broader theme of cross-border labor migration to Europe, this article looks at the less explored topic of female Ukrainian migrants in receiving countries of Western Europe. More specifically, it will look at the impact it makes on the sending country of Ukraine. Using a case study approach, it will analyze available research on the topic and identify the effects that cross border wage labor migration makes on the Ukrainian family and on the development of the emerging civil society in Ukraine. The study develops its argument in three parts. The first part of the article offers a summary of the background research on civil society, international migration; the second one discusses the theoretical issues underpinning this research; and the third part of the article analyzes the evidence gathered on 
social challenges caused by working migration, their reasons and consequences. It also analyzes socio-economic factors of Ukrainian family functioning, the specifics of family motivation for working migration, and the influences of cross-border migration on the members of sending families. The aim of the article is two-fold: to enrich the pool of knowledge on Ukrainian female migrants to Europe, and to engage with recent literature on the role that transnational migration plays in relation to the family and its sending country as part of transnational civil society.

\section{THE RETROSPECT ANALYSIS OF CIVIL SOCIETY THEMES}

There is strong research evidence that civil society helps to advance democracy. "A democracy - according to a long line of scholars from Aristotle to Robert Dahl - cannot function without a vibrant and autonomous civil society" (Sanchez 1999, p. 25). It can promote political participation and ensure that citizens' interests are taken seriously (Patrick 1996). Civil society can promote democratic consolidation of citizens, and build trust in their relations with each other and promote the consolidation of democratic governance. Trust is essential to the effectiveness of civil society functioning because social trust and civic involvement are strongly correlated (Putnam 1995, p. 665).

Civil society is not a new concept. Having been developed in the works of Cicero and other Roman and ancient Greek philosophies, the term entered the political language through Latin translation of societas civilis, originally defined by Aristotle's koinonia politike as a "community of humans united within a legitimate political order" (Khilnani 2001, p. 17). The modern concept of civil society emerged in the Enlightenment of the late $18^{\text {th }}$ century under the influence of changing economic realities and a growing demand for liberty (Carothers, Barndt 1999-2000) and stems from the conceptualization by scholars such as Jean Jacques Rousseau, Immanuel Kant, John Locke, Adam Smith, Adam Ferguson, Alexis de Tocqueville, George Hegel, Karl Marx and Antonio Gramsci. Despite all the different definitions, the concept of civil society was based on the opposition to the state and a way for the public to express its will. J. J. Rousseau connected the growth of civil society with private property and personal responsibility for other people's property: "the first one who fenced a piece of land and claimed it to be his, and found people good enough to respect it, was the genuine founder of civil society!" (Rousseau 1965, p. 108). I. Kant understood this term as "a society of universal rights" and "only there the biggest development of natural skills is possible" (Kant 1966, p. 465). However, political philosophers of the $17-18^{\text {th }}$ centuries (except for J. Locke) did not have a clear distinction between civil society and the state.

The German tradition situated civil society as the opposition to the state. G. Hegel was the first to separate the nature of civic and political life of citizens elaborating the notion of civil society as "a domain parallel to but separate from the state - a realm where citizens associate according to their own interests and wishes" (Carothers, Barndt 1999-2000, p. 18). Hegel was the first who considered attributive characteristics of civil society (Kant 1966). He connected its development with a family. He believed that with time one family splits into many, relationships of which represent not just 
some inner unity, but something rather wider. Hegel called it a "degree of differentiation", when morality which made the basis of the family is being lost: exactly here, he believed, the transition from the family toward civil society is happening (Kant 1966, p. 465). He defined three elements of civil society: (1) a system of needs; (2) defense of private property by the state; (3) police and corporation. When it comes to needs, he meant foremost human labor which promotes personal freedom and social responsibility (Kant 1966, p. 239). To defend private property, there should be a system of adequate, clearly and simply formulated laws established which all the citizens must know and follow. And in civil society, he continued, individuals have to think and to act freely to achieve their goals; and the task of the police is to guarantee them such a possibility and defend them. The people, in return, have to follow all the duties of civil society, honestly work for it, feel personal responsibility for the interests of civil society and celebrate their rights (Kant 1966, p. 267).

K. Marx and Friedrich Engels (Marx, Engels 1987) used the term "civil society" quite often, but gave a totally different meaning to it. Foremost, they meant "real" industrial relationships and communication in process of production in the conditions of bourgeois society which were understood synonymously with civil society (Marx, Engels 1987, p. 35). If F. Engels defined civil society as the "kingdom of economic relations" and claimed political economy as a "science of civil society" (Marx, Engels 1987, p. 35), then K. Marx referred to it as a social organization shaped by a certain mutual industrial production and communication. Unlike previous idealistic theories claiming that social development is defined either by human consciousness or God's will, K. Marx and F. Engels showed that the development of civil society is a natural historical process. People create their history, but the procedure of social development is not defined by their free will and desires, but rather by their material conditions of living which form all the spheres of their social life such as state, politics, morality, religion and philosophy.

The concept of civil society was cast off in the mid-19 $19^{\text {th }}$ century as philosophers turned their interest towards the social costs of industrial revolution, and got back into use after World War II in the works of the Marxist theorist A. Gramsci. His books were influential in the 1970s and 1980s with people fighting against authoritarian regimes in Central and Eastern Europe, Latin America (Carothers, Barndt 1999-2000). The fall of the Berlin wall, the activity of Polish Solidarność, the Gorbachev perestroika and glasnost', the collapse of the Soviet Union sped up the process of social renewal, empowered citizens and opened the space for civil society formation in the countries of the post-cold-war world of the former Soviet bloc.

There are various interpretations of what constitutes civil society and the diversity in these interpretations has reshaped the concept since the mid-19 ${ }^{\text {th }}$ century. Referring to Adam B. Seligman (Seligman 1992), put it in the broad concept of the "problematic relation between the private and the public, the individual and the social, public ethics and individual interest, individual passions and public concerns". It is also referred to as the "third sector", distinct from government and business. In this view, the term refers to intermediary institutions that give voice to various sectors of society and enrich public participation in democracies and transitional societies (What is Civil Society 2003). 
In recent years there has been a dramatic increase in the size and capacity of civil society around the world, as reported by the World Bank. Non-governmental organizations constitute an important part of civil society and according to the World Bank, there had been 6,000 international NGOs in 1990 and the number had increased to 50,000 in 2006. However, it is important to note that even though local and indigenous non-governmental organizations have been called the 'building blocks of civil society' (Grodsky 2009, p. 902) not all NGOs are considered to be civil society per se. Many are private international organizations, such as Greenpeace, Amnesty International, or the Red Cross that work throughout countries but are not considered to be independent civic groups that arise independently from a grassroots social movement. Such organizations provide irreplaceable aid to those in need, but they do not represent independent indigenous associations. This definition of civil society includes the complex network of freely formed, self-generating, self-supporting associations that are autonomous from the state, and bound by a legal order or set of shared rules. Overall, this definition refers to a public domain that private citizens create and operate, acting in their interests, distinct from the state but not necessarily in conflict with it (Patrick 1996, Diamond 2004). Civil society organizations act as an independent social force that checks and limits the power of the state.

For the purposes of this study, a conducted retrospect analysis of civil society themes allowed defining a number of its common characteristics which seem to be necessary for it to function successfully: (1) functioning under the rule of law; (2) personal freedom and responsibility; (3) personal initiative, mobility and participation; (4) legal existence of non-state sponsored groups and organizations; (5) respect for the rights, interests of others and one's own dignity; (6) respect for private and public property including private property of others; (7) civic duties and rights; (8) harmonious unity of patriotic and international feelings of citizens.

\section{DOES CIVIL SOCIETY REALLY EXIST IN UKRAINE?}

The collapse of the Soviet Union was, probably, one of the most dramatic events of the $20^{\text {th }}$ century. The state of social transformation, experienced by its former republics, is connected with both great economic difficulties (such as demographic cataclysms, migration, unemployment, impoverishment of middle class), and extreme social situations characterizing post-conflict development of eastern European countries. In these countries, the break becomes deeper between initially expected changes and the present state of social and political reforms; between the formation of regional systems and competition of the states; and between expectations of international donors and local realities. Foreign direct investments are minimal. The judicial systems are largely dysfunctional. While much new legislation is of high quality, it is not always implemented efficiently. Corruption remains a serious problem.

Ukraine is an illustrative example of great political instability that characterizes Eastern Europe during its transition from authoritarian regimes to democracy. Social reforms aimed at building civil societies in these countries turned out to be unsuccessful (Vaillant 2005). Researchers connect this with the processes of social anomie, collapse of traditional values, disorientation of the person in the transi- 
tional society and absence of the concepts of democracy and legal state (Shevchuk 2006). This resulted in the disintegration of the traditional family; unemployment; emigration; as well as corruption at all levels of the society; criminality; public polarization; rapid and mass impoverishment of the population.

Freedom House measures the progress towards democratic freedoms worldwide by assessing a series of questions in six categories: electoral process; civil society; independent media; governance and public administration; rule of law; and, corruption. Progress towards each category is rated on a six-category scale, 1 representing the most advanced and 6 the least advanced. Its study, Nations in Transit 2011 (http:// www.freedomhouse.org/report/nations-transit/nations-transit-2011), shows that post-Communist states continue to lag behind in key areas of democratic development. According to the 2011 ranking of Freedom House, in such a transitional country, as Ukraine, the process of corruption is very high (with a median of 5.75). In 2011, Ukraine's civil liberties rating declined from 2 to 3 and its status of freedom changed from "Free" to "Partly Free". Among the reasons of such a decline, the Freedom House Freedom in the World 2011 (http:/ / www.freedomhouse.org/report/freedom-world/ freedom-world-2011) indicates the deterioration "of media freedom, secret service pressure on universities to keep students from participating in protests, government hostility toward opposition gatherings and foreign nongovernmental organizations, and an increase in presidential influence over the judiciary" (http:/ /www.freedomhouse.org/report/freedom-world/freedom-world-2011, p. 34).

Numerous surveys conducted in Ukraine attest to the seriousness of political and social challenges in Ukraine (Hapon 2008). According to the surveys conducted by Nadiya Hapon (Hapon 2008), today $10 \%$ of Ukrainians will confidently vote for a political party with leaders accused of corruption, bribery or in other criminal activity; and another $25 \%$ of Ukrainians are potentially ready to do it. According to the data of the World Bank, real unemployment in Ukraine reached $30 \%$ of its population (Social Indicator of Population 2005).

Speaking about the level of civil society development in Ukraine as compared against the eight defined characteristics of civil society, the study argues that it is too early to conclude that civil society really exists in Ukraine. On a positive note, the end of cold war, growing globalization connected with social and economic challenges of post-socialist Ukraine, made a strong impact on many members of Ukrainian population toward exercising their personal freedoms, developing own initiative, and making personal choices regarding crossing the borders and becoming wage labor migrants in search of additional income to support their families in the home country. Probably, this social mobility factor could be considered the only indicator of emerging civil society in Ukraine which has a long way to go before the conditions for other civic factors develop.

\section{GLOBAL ISSUES OF INTERNATIONAL WAGE LABOR MIGRATION}

The global migration of labor is an important component of globalization which promotes the economic development of many countries with transitional economies and emerging civil societies. The influence of international labor migration from the 
perspective of its home country has become the focus of many studies throughout the recent decade (Tolstokorova 2009, Psimmenos, Skamnakis 2007, Górny, Kępińska 2004 and others). A number of researchers explore the influence of international migration in a broader scope of a global cultural diffusion, the developmental impact of remittances on the future of families, labor immigrants and their children (Guarnizo, Díaz 1999, Edwards, Ureta 2003, Feliciano 2006, Levitt 2001, Levitt 1998). Another group of scholars has addressed the issues of irregular migration which promotes the growth of shadow economies predominantly in southern and central Europe and fosters the climate of economic dependency in sending regions (Düvell 2006, Drbohlav, Medova 2010, Divinsky 2010, Fasani 2010).

While it may be true that wage migrant-sending households rely on remittances to increase consumption, international migration also produces benefits because families can also use this money to sustain schooling of younger family members. Research by Edward J. Taylor, Jorge Mora, Richard H. Adams, Alejandro Lopez-Feldman (Taylor, Mora, Adams, Lopez-Feldman 2005) provides evidence to this assumption, showing that remittances help to loosen up credit constraints among receiving family members, enabling them to invest more substantially in their children's education.

Others working in this tradition have taken a definitely more negative approach, concentrating their attention on the negative aspects of cross-border migration (Hapon 2004). International migration can be a risky business. On the one hand, studies discuss the reasons of why some migrants fail to reach the country of their destination (were detained at the border, fell victim to unscrupulous smugglers), or why some succeed in migrating but fail to remit (Taylor, Mora, Adams, Lopez-Feldman 2005). There is some doubt that the loss of population to cross-border migration creates negative effects on transitional economies in migrant-sending areas because losing these individuals who leave for foreign labor markets may not have a very large impact on the development of production in their home countries.

Research also provides evidence to the fact that cross-border migration impacts men and women differently. Today, the share of females in the world's international migrant population is close to one half, but there are differences among sending and receiving countries (Montefusco 2008). The share of females in migration to some countries is higher than that of males (Taylor, Mora, Adams, Lopez-Feldman 2005). Emigration is especially strong in the post-socialist countries of Eastern Europe. According to Christina Montefusco who studied worldwide emigration of women, there are 7 million women migrant laborers from Ukraine (out of 48 million of the Ukraine's population) (Montefusco 2008).

There is a strong research support on the problem of feminization of international labor migration. Today, the wage labor migration has created the so called "skill drain" concept, along with the problem of "care drain". Women are normally the primary care providers in the families and their going away unavoidably deprives those who need care most: especially, their children and elderly parents. It is not unexpected that the media and NGOs in Romania have begun to talk of the "de facto abandonment" (Piperno 2007) while, in Ukraine, it is now quite normal to talk of "social orphans". 
Most recent trends of research on labor migration are studies on female care workers as agents of "care gain". The female emigration does not necessarily produce just a "care drain". Women go on providing care even when they are abroad. According to Flavia Piperno (Piperno 2007), who studied Ukrainian and Romanian female care workers in Italy believes that, "ad hoc policies can sustain and foster the role of women as welfare providers, putting in place strategies that support communication between mothers abroad and their places of origin, such as those aimed at improving the management of long-distance parenting, limiting the negative impact of care drain and strengthening the intervention of local welfare actors working with minors left behind in the homeland" (Piperno 2007, p. 64). Indeed, the work of teachers and educators, for instance, is much less effective if performed in isolation, or in a distance.

Taken together, these perspectives articulate a very general description of cross-border labor migration and its effect on sending and receiving areas. Cross-border transactions of funds and movements of people, morals, and emotional support obviously rearrange the social, cultural, and economic spheres in places of origin. These changes have solid costs for people, and particularly, for children.

\section{CONTEXTUAL BACKGROUND: UKRAINE AS A SENDING COUNTRY FOR WAGE-LABOR MIGRATION}

The population of Ukraine has drastically decreased from 52.2 million in 1992 to 46.3 million in 2011 (Sushko, Prystayko 2011) due to migration and low birth rate caused by low salaries and a relatively low quality of life (Vollmer, Bilan, Lapshyna, Vdovstova 2010). The name "Ukraine", or Ukrajina, literary means "borderland", and unfortunately the geopolitical role of the country accurately corresponds to this meaning. Because of its geographical situation in Europe bordering the Eurasian country of Russia, it is considered to be the "buffer state" between Russia and NATO countries. It is also considered to be the "sanitary border" of Western Europe, keeping out the treat from the east (Mikhel 2009). Ukraine is divided into twenty five administrative regions (Oblast') and is divided into east and west by a river Dniepr. This involuntary division also seems to be separating the country ideologically and linguistically, where the western part of Ukraine is pro EU and is the main supplier of emigrants into the European countries, and the eastern part supports and provides short term emigrants to Russia.

The collapse of the USSR provided people with the ability to freely travel, no longer locked behind the "iron curtain". Internal and external mobility became a strong tool for economic transformation of the society and stabilization of the labor force. In the early 1990s more than fifty percent of the Ukrainian population has expressed aspirations of leaving the country (Shevstova 1992) and right now there are more than seven million emigrants living abroad (World Development Report 2006).

According to the research of the State Institute for Problems of Families and Youth, the biggest number of working migrants originate from region centers, smaller towns and villages. The age category of people that leave the country are secondary education graduates and also people between the ages of 25-27, most of whom already have families (50-60\% already have children) (Hapon 2008, p. 100). 
It is important to mention that since there is such a strong demand for emigration, this trend activates the need for criminal groups specializing in preparing emigration documents and getting people across borders with the aim of human trafficking. In 1999-2009 according to data provided by the Ministry of Internal Affairs, 1279 human trafficking incidents were prosecuted, and every year this number increases (Hapon 2008).

Because of current social anomie, today's Ukrainian economy is heavily dependent on remittances from female migrants working abroad. According to the data of Ministry of Foreign Affairs of Ukraine, currently there are more than two million Ukrainians working illegally abroad (Hazratova 2004, Social Indicator of Population 2005). A representative of Supreme Council of Ukraine on Human Rights believed that this number was significantly lowered and in 2005 there were at least five million Ukrainian citizens, mostly women, working abroad (Hapon 2008).

\section{THE REASONS FOR OVER-BOARD MIGRATION AND ITS QUANTITATIVE PARAMETERS IN UKRAINE}

According to the World Bank Report (The World Bank Annual Report 2007) Ukraine ranks very high on the list of sending and receiving countries of human capital. Ukraine has a strong respect for education and therefore has a well organized traditionally based system of education. In recent years there have been substantial educational reforms, for example the Bologna Process, which transformed the Soviet secondary and higher education according to the requirements of the European Union. The current level of literacy is 99.4 percent (where men are 99.7 and women 99.2). With these high levels of literacy and noteworthy levels of completed higher education institutions most of the migrant workers are significantly overqualified for the jobs they receive abroad.

It is a country of emigration, and of increasing immigration from all parts of the world. The country ranks third of the sending countries, even before such densely populated countries as China and India, and it also counts as a fourth receiving country, after Germany (The World Bank Annual Report 2007). With such a strong labor migration movement it is no surprise that the traditional values of a Ukrainian family are starting to drastically change. The same report also shows that ten percent of the Ukrainian population works abroad on a temporary basis and Ukraine is the major port of departure for the migrant workers to Europe. It is a generally known fact among the citizens of the country that due to strong corruption forces it is relatively easy to obtain visas to European countries and some because border control is not as strong (especially on the eastern side bordering Russia), it is possible to enter Russia and migrate eastward without difficulties (Duvell 2011, p. 1).

Barbara Dietz argues that the reasoning for labor migration has changed over the years of Independence. Right after the break up of the USSR immigration was caused by political reasons of overall instability and ethnic intolerance (which was unacceptable during the years of communism based on the Marxist ideology), which changed to motives driven by economic reasons of self enrichment in the mid-late 1990s (Dietz 2007). 
N. Hapon argues that the anomic reasons for migration are motivated by better work opportunities by the family members. Several years ago the biggest stimulus for labor migration was the high level of unemployment but today the main reason is the generally low salaries, which do not allow families to cross the poverty line. Today the low salaries don't allow families to cross the poverty line despite families' eagerness to change low paying professional work place (doctors and medical workers, teachers, where the majority are women) to lower status occupation which is paid higher. The race for higher wages pushes the working age citizens of Ukraine to pursue labor migration abroad and leave families behind. Even though the economic situation has increased in the country, the strong pull toward better opportunities has not slowed down the migration movement. Close to forty seven percent of the working age population is ready to leave Ukraine at any moment and spouses are willing to let their partners go abroad for years (Hapon 2008).

Another strong reason for migration is the "myth of Europe", which represents a more just and socially stable society, where crime, corruption and bribery and almost invisible. The rule of law and protection of human dignity and rights are based on the idea of liberté, egalité, fraternité, which is strongly present in the minds of Ukrainian people in their vision of Europe. Even though there is a strong presence of human rights protection in the Ukrainian Constitution, the actual respect for these rights and basic human dignity is visibly lacking in the society.

Strong attention must be paid to the issue of trafficking. In 1998 close to 400 thousand women were trafficked during the previous decade. A popular method of female trafficking was offering young women temporary opportunities to be a nanny for a few months. An even more common occurrence was organizing modeling auditions followed by contracts to Western European countries, where they were then primarily smuggled to the countries of the Middle East and Turkey, Greece, Cyprus, Yugoslavia, Hungary, the Netherlands, etc., and sold into prostitution (Hughes 2000).

Nevertheless, despite the risks of overboard migration, according to the data of sociological surveys, every third respondent still wishes to go work outside of Ukraine for a few months, every fifth respondent wishes to leave for a few years, and every tenth respondent wants to leave for good. The largest percentage of those wishing to leave are the people with families and children (Hapon 2008).

\section{MAIN IMPACTS OF FEMALE WAGE-LABOR MIGRATION ON THE SENDING FAMILIES}

The major impact of wage-labor migration is socially negative because it is connected with the disintegration of the traditional Ukrainian family. It can be stated that the family is a strong part of the socialization of children regardless of the country of origin. However, there are strong indicators that the institution of family is slowly loosing its primary role in the process of the social control during the transition to the free market economy (Tolstokorova 2009).

Migration dramatically promotes increasing the numbers of social orphans, or children abandoned by their parent(s) in search of better incomes to sustain their children and families left in Ukraine or to increase material welfare. Because 
of massive internal and external migrations the permanent location of people's living has lost its stability. For the majority of the population, overcoming poverty has become impossible in the near future. People do not feel safe either, because of the absence of social programs.

This process of an international migration has created issues not only with the decreased population growth and fertility, but also is an increasing cause for divorces (Social Indicator of Population 2005). Although the issue of migration in Ukraine has not been explored enough until recently, there has been strong attention paid to female labor migration and its effect on family structure (Kyzyma 2007). Scholars (Kyzyma 2007) specifically analyzed the effect of emigration on gender roles and women's status, as well as the children that were left behind and their disrupted lives, the so called "social orphans syndrome".

The new transnational families can have both positive and negative effects on the situation of the children left behind (depending on the nature of migration and its duration). There also are differences among these new family forms, including whether all family members live together, one or both parents and away from their children and if there are other members of the family watching over the children.

Among negative consequences of emigration, there are the destroyed families and unattended children abandoned by their parents who work abroad providing for their family in Ukraine, the loss of work potential of professional qualification of Ukrainian fellow citizens, who usually do tough physical work abroad. This means that about half of Ukrainian citizens represent potential risk group, and can also become victims of human trafficking. The situation is especially difficult in western regions of Ukraine: Rivne, Ternopil, Chernivtsi, Volyn', Zakarpat and Lviv regions, where more than one member of a family is working abroad.

It is generally known that the children left behind in Ukraine while their parents are abroad do have a better economic status than the rest, they receive a better education, they have access to better communication technology and they even dress better, all of which increases their economic status in the eyes of everyone else. This also causes a problem of these children not respecting the work their parents do, and since there is no direct control over their actions, especially in their teenage adolescent years, many turn to crime, drugs and alcohol and are able to get away with these actions without much punishment from their families or the law, thanks to the financial corruption of law enforcement. Teenagers have more opportunities for socialization, they are able to participate in pricy activities and therefore raise their social status in the eyes of their peers without having to put any work into their social success. This is especially noticeable in the Western regions of Ukraine, where it borders Poland, Hungary, Slovakia, Romania and Moldova and there are many possibilities and easier means of travel abroad. Knowing this from personal experience, it is possible to visit rural places Western regions of Ukraine where most of the female population of a village or a town is working abroad, leaving their children behind who lack not only maternal or for that matter paternal support, driving around in expensive cars and living an expensive lifestyle. Many of these adolescents do not care for education or personal development, and attend higher education institutions mainly for social standing and future opportunities to travel. 
In a recent study of Ukrainian women working in Italy, 94\% of the interviewed subjects have children living in Ukraine, who most often stay with their elderly grandparents unable to provide proper support and control, or with the father, who is also working. 33\% of these women have children living unattended. In the Western Ukraine these youth have a nickname of "Italian children" because one or both of their parents are working not only in Italy, but in other European countries. Because these "Italian children" lack parental pedagogical guidance, they are generally considered to be "problem children" by the society. Labor migration does not only create a problem of parents distant from their children, but also that it loosens kinship ties and the connection between spouses and other family members, slowly transforming the generally known traditional society with long-established customs and traditional gender roles into one with lack of values and emotional connection between families. This in turn leads to higher crime rate, neglect of elderly family members and other sociological problems (Tolstokorova 2009).

The power of increasing financial oligarchies is slowly pushing out the power of the Ukrainian government, leading to the decrease of the family welfare. Now the "market" is becoming the universal power in its most cruel form, where the humanitarian values are lower than material good on the hierarchical scale. A large number of families remain under the poverty line and beyond the system of social assistance. The system of social assistance is too small to effectively stabilize the living standards of families. Migration therefore is the answer to the mobilization of family members caused by low paying jobs or even their absence.

\section{THE INFLUENCE OF WAGE LABOR MIGRATION ON THE DEVELOPMENT OF CIVIL SOCIETY IN UKRAINE}

The transnational wage-labor migration promoted strong internal and outer social mobility of Ukrainian citizens that wanted to financially and materially provide for the family. In the 1990s the country's minimum wage was substantially lower than needed for survival, which became a powerful factor of migration and family decline. Another challenge is connected with a rapid decrease of the middle class and its insufficient influences on social political and economic development of the country. The rapid population impoverishment, the realities of rapidly increasing unemployment, ineffective social security are becoming particularly noticeable in Ukraine.

This tremendous decline and differentiation of the Ukrainian society has transformed into dangerous social polarizing - to very poor and very rich. Usually, migrants' remittances help their sending families to become richer than they were just a couple of years before. This enrichment pushes migrants to work even more for additional income outside of Ukrainian borders. Besides this, the pursuit of high income, expensive things, migrants' desire to provide for their children's education in the most prestigious universities, for the majority of people, became the main purpose and the reason to prolonging the migration status of the family members (father or mother). Deformed understanding of the role of the family, career, health by the migrant workers was also supported by the government politics, which have been imprinted at the demographic level. 
At the same time, transnational and international migration to the European Union promotes people's social mobility, activeness, entrepreneur skills, and strengthens the role of market forces in migrants' path ways to inclusion in the social and economic system of the receiving society. Often migrants find themselves trapped by political and market forces of sending and receiving countries and locked in contradiction over their own perception of themselves. In fact, the overwhelming majority of Ukrainian migrants learn the lessons that free access to the labor market is the crucial step towards overcoming the so-called 'liberal paradox" of migration politics of the sending and receiving country, and to the successful integration of migrants into the host society.

Female migrants, providing care to people in their host country, simultaneously also try to provide care to their sending families, though at a distance. By living this dual life, they develop personal ties with host country members, emotional attachments and eventual acceptance of the receiving country's culture and its people, while maintaining strong emotional and financial connections with sending families. This leads to developing a marginal type of a person with a broader worldview, with genuine caring for a bigger group of people from different cultures than just for their counterparts (as they used to do before becoming migrants). This promotes developing their civic consciousness, thinking about others who are different, and eventual caring for common good for the sake of the so called transnational civil society.

\section{CONCLUSION}

Globalization, integration processes in all of the spheres of human work, promoted by Ukraine's entering the global work market, has created an outside and inside social mobility of family members, their migration across the borders and especially illegal migration. It resulted in destroyed families, unattended children, victims of human trafficking. The study showed that for decreasing of negative aspects of migration processes in Ukraine, it is necessary to use all positive resources of informational society, such as increasing social communication and bringing back the traditional values of a Ukrainian family.

The findings of this research have a twofold nature. On the one hand, they have shown that the financial resources that wage labor migration brings have a positive effect on households' budgets, leading to increased consumer spending and, consequently, additional demand in the labor market for new workers. On the other hand, within the broader theme of working migration to Europe, wage labor migrants slowly integrate socially and economically into their receiving countries. They learn to exercise in reality the democratic values of Western culture by gradually exporting them to their cross border homeland, along with remittances and the capitalist work ethic. This transnational civil society can promote democratic consolidation of citizens of different nations, build trust in their relations with each other and promote the consolidation of democratic governance. Trust is essential to the effectiveness of the emerging civil society functioning because social trust and civic involvement are strongly correlated. 


\section{BIBLIOGRAPHY}

Carothers T., Barndt W. (1999-2000), Civil society, “Foreign Policy” 117.

Clayton A., Oakley P., Taylor J. (2000), Civil society organizations and service provision, United Nations Research Institute for Social Development, Geneva.

Diamond L. (2004), What Civil Society Can Do to Develop Democracy. Presentation to NGO Leaders, Convention Center, Baghdad.

Divinsky B. (2010), Slovakia: irregular migration - from old challenges to new, [in:] Triandafyllidou A. (ed.), Irregular Migration in Europe: Myths and Realities, Ashgate, Aldershot.

Dietz B. (2007), Migration policy challenges at the new Eastern borders of the enlarged European Union: The Ukrainian case, "Osteuropa-Institut München. Working Papers" 267.

Drbohlav D., Medova L. (2010), Czech Republic: irregular migration -"old wine in new bottles", [in:] Triandafyllidou A. (ed.), Irregular Migration in Europe: Myths and Realities, Ashgate, Aldershot.

Düvell F. (ed.) (2006), Illegal Migration in Europe: beyond control?, Palgrave MacMillan, New York.

Düvell F. (2006), Undocumented migration in Europe: a comparative perspective, [in:] Düvell F. (ed.), Illegal Migration in Europe: beyond control?, Palgrave MacMillan, New York.

Edwards A. C., Ureta M. (2003), International migration, remittances, and schooling: Evidence from El Salvador, "Journal of Development Economics" 72.

Eklof B., Holmes L., Kaplan V. (eds.) (2005), Educational Reform in Post-Soviet Russia: Legacies and Prospects, Frank Cas, London - New York.

Fasani F. (2010), The quest for la dolce vita? Undocumented migration in Italy, [in:] Triandafyllidou A. (ed.), Irregular Migration in Europe: Myths and Realities, Ashgate, Aldershot.

Feliciano C. (2006), Beyond the family: The influence of premigration group status on the educational expectations of immigrants' children, "Sociology of Education" 79.

Gorbaniuk J. (ed.) (2007), The Situation of the Family in Contemporary Society - Experiences of Middle Eastern Europe, Publishing House of Catholic University of Lublin, Lublin.

Górny A., Kępińska E. (2004), Mixed marriages in migration from Ukraine to Poland, "Journal of Ethnic and Migration Studies" 31(3).

Grodsky B. (2009), From neo-corporatism to delegative corporatism? Empowerment of NGOs during early democratization, "Democratization" 16(5).

Guarnizo L., Díaz L.M. (1999), Transnational migration: A view from Colombia, “Ethnic and Racial Studies” 22.

Hapon N. (2004), Gender and Education: Psychological Research of Students' Imaginations, [in:] Kucha R. (ed.), European Integration through Education: Traditions the Present and the Future, Maria Curie-Sklodowska University Press, Lublin.

Hapon N. (2007), The Ukrainian family under the Influence of Globalization and Migration Processes, [in:] Gorbaniuk J. (ed.), The Situation of the Family in Contemporary Society - Experiences of Middle - Eastern Europe, Publishing House of Catholic University of Lublin, Lublin.

Hapon N. (2008), The Ukrainian family and work-related emigration: Realities and perspectives, [in:] Marcowski K. (ed.), Migration - is the Value Added?, Publishing House of Catholic University of Lublin, Lublin.

Hazratova N. (2004), Психологія Відносин особистості ӥ держави [Psychology of Relationships of a Person and a State], Vezha, Lutsk.

Hughes D. (2000), The "Natasha trade": The Transnational shadow market of trafficking in women, "Journal of International Affairs" 53(2).

Iglicka K., Weinar A. (2008), Ukrainian migration in Poland from the perspective of Polish policies and systems' theory, "Journal of Immigrant and Refugee Studies" 6(3).

Kant I. (1966), Идея всеобщей истории во всемирно-гражданском плане [The Idea of universal history in a global civic aspect], Moscow.

Kapur D. (2005), Remittances: The new development mantra?, [in:] Maimbo S. M., Ratha D. (eds.), Remittances: Development impact and future prospects, The World Bank, Washington.

Kaviraj S., Khilnani S. (eds.) (2001), Civil society: History and possibilities, Cambridge University Press, Cambridge.

Khilnani S. (2001), The development of civil society, [in:] Kaviraj S., Khilnani S. (eds.), Civil society: History and possibilities, Cambridge University Press, Cambridge.

Kucha R. (ed.) (2004), European Integration through Education: Traditions the Present and the Future, Maria Curie-Sklodowska University Press, Lublin. 
Maimbo S. M., Ratha D. (eds.) (2005), Remittances: Development impact and future prospects, The World Bank, Washington.

Marcowski K. (ed.), Migration - is the Value Added?, Publishing House of Catholic University of Lublin, Lublin.

Marx K., Engels F. (1987), German Ideology, Political Literature, Moscow.

Mikhel D. (2009), Osnovni aspekty geopolitychnogo polozhennja Ukrainy ta ii zovnichnjopolitychnyj vymir, "Journal of Politology" 97.

Montefusco Ch. (2008), Ukrainian Migration to Italy, "Journal of Immigrant Refugee Studies" 6(3).

Levitt P. (1998), Social remittances: Migration driven local-level forms of cultural diffusion, "International Migration Review" 32.

Levitt P. (2001), The transnational villagers, University of California Press, Berkeley.

Piperno F. (2007), From Care Drain to Care Gain: Migration in Romania and Ukraine and the Rise of Transnational Welfare, "Development" 50(4).

Putnam R. D. (1995), Tuning in, Tuning out: The Strange Disappearance of Social Capital in America, "Political Science and Politics" 28.

Rousseau J.J. (1965), Discours sur l'origine et les fondements de l'indgalite parmi les hommes, Presses Pockets, Paris.

Sanchez P. (2007), Panama Lost? US Hegemony, Democracy and the Canal, University Press of Florida, Florida.

Seligman A.B. (1992), The idea of civil society, Maxwell Macmillan International, York.

Shevstova L. (1992), Post-Soviet Emigration Today and Tomorrow, "International Migration Review" 26(2).

Shevchuk L. (2006), Проблеми індивідуального й суспільного здоров'я в контексті трансформації соціальної мобільності [Problems of individual and social health in the context of transformation of social mobility], “Соціогуманітрані проблеми людини" [Social and Humanitarian Problems of a Person] 2.

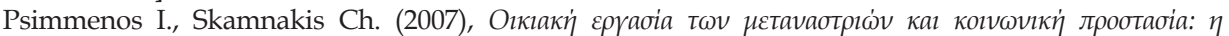

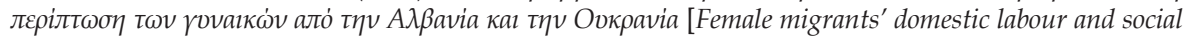
welfare: The case of Albanian and Ukrainian women], Papazisiz, Athens.

Social Indicator of Population (2005), The State Committee of Statistics of Ukraine.

Taylor J., Mora J., Adams R., Lopez-Feldman A. (2005), Remittances, Inequality and Poverty: Evidence from Rural Mexico, University of California, Davis.

Triandafyllidou A. (ed.) (2010), Irregular Migration in Europe: Myths and Realities, Ashgate, Aldershot.

Vailllant J. (2005), Civic education in a changing Russia, [in:] Eklof B., Holmes L., Kaplan V. (eds.), Educational Reform in Post-Soviet Russia: Legacies and Prospects, Frank Cas, London - New York.

World Development Report (2006), World Bank, Washington.

\section{NETOGRAPHY}

Duvell F. (2011), Ukraine - Europe's Mexico? [in:] Central and Eastern European Migration. Research Resources Report 1/3: Country Profile, http://www.compas.ox.ac.uk/fileadmin/files/pdfs/Non_WP_pdfs/Transit_Migration_in_Ukraine/Ukraine_Country\%20Report_1of3.pdf, retrieved: 25.01.2011.

Freedom in the World 2011, http://www.freedomhouse.org/report/freedom-world/freedomworld-2011, retrieved: 31.03.2012.

Kyzyma I. (2007), Determinants and Consequences of Female Labor Migration from Rural Areas: The Case of Ukraine, http:/ / www.mace-events.org/greenweek2009/5808-MACE.html, retrieved: 01.04.2012.

Massey D. S. (1990), The social and economic origins of immigration, "The Annals of the American Academy of Political and Social Science" 510, http://repositories.cdlib.org/are/arewp/05-003/ retrieved: 18.11.2011.

Nations in Transit 2011, http://www.freedomhouse.org/report/nations-transit/nations-transit-2011, retrieved: 31.03.2012.

Patrick J. (1996), Civil Society in Democracy's Third Wave: Implications for Civic Education, http:/ / www. eric.ed.gov/PDFS/ED406297.pdf, retrieved: 20.11.2011.

Sushko O., Prystayko O. (2011), Ukraine, http:/ / www.freedomhouse.eu/images/Reports/NIT-2010Ukraine-final.pdf, retrieved: 25.01.2011. 
The Authoritarian Challenge to Democracy: Selected data from Freedom House's annual survey of political rights and civil liberties (2011), [in:] http://www.freedomhouse.org/images/File/fiw/FIW_2011_Booklet.pdf, retrieved: 18.11.2011.

Tolstokorova A. (2009), Costs and Benefits of Labour Migration for Ukrainian Transnational Families: Connection or Consumption?, http:/ / urmis.revues.org/index868.html, retrieved: 10.06.2009.

Vollmer B., Bilan Y., Lapshyna I., Vdovtsova S. (2010), Ukraine: Country and Research Areas Report, http://www.eumagine.org/outputs/PP3\%20-\%20Ukraine\%20Country\%20and\%20Research\%20 Areas\%20Report.pdf, retrieved: 30.03.2012.

What is Civil Society (2003), [in:] Civil Society International, http://www.civilsoc.org/whatisCS.htm, retrieved: 20.03.2011.

The World Bank Annual Report 2006 (2006), http://siteresources.worldbank.org/INTANNREP2K6/ Resources/2838485-1158333614345/AR06_final_LO_RES.pdf, retrieved: 01.04.2012.

The World Bank Annual Report 2007 (2007) http://siteresources.worldbank.org/EXTANNREP2K7/ Resources/English.pdf, retrieved: 01.04.2012. 